\title{
KETAHANAN KREDIT PERBANKAN SYARIAH TERHADAP KRISIS KEUANGAN GLOBAL
}

\author{
Ihda A Faiz ${ }^{1}$
}

\begin{abstract}
Global financial market becomes fragile and unstable today after bigfinancial crisis (subprime mortgage) hited almost country around the world. Recently, solvability ratio or credit risk becomes focus study again by economic expertise to prevent repreated crisis. The purpose of this paper is to investigate Islamic credit resistant of Islamic banks during global financial crisis in Indonesia. The results of this study show that the amount of Islamic financing and GDP were significantly determined by non-performing financing (NPF). In the other side, conventional banks were influenced positively by inflation rate and Loan to Deposit Ratio (LDR). These findings show the empirical evidence how Islamic banking and economic systems can reduce the effect of global financial crisis significantly to domestic society.
\end{abstract}

Keywords: NPL, NPF, banking stability

\section{PENDAHULUAN}

Permodalan merupakan hal yang cukup urgen bagi berkembangnya sebuah usaha, tidak terkecuali bagi usaha kecil menengah (UKM). Salah satu opsi yang dapat dipilih para pengusaha untuk meningkatkan kinerja dan perkembangan usaha mereka adalah dengan mendapatkan kredit dari perbankan. Bagi UKM, kredit merupakan faktor penting akselarasi usaha mereka. Karena itu kalangan perbankan harusnya memberikan porsi yang cukup besar untuk skim penyaluran kredit bagi UKM mengingat pentingnya peran UKM dalam pengentasan pengangguran ${ }^{2}$ dan kontributor perekonomian nasional yang signifikan ${ }^{3}$. Dengan keberpihakan pada UKM diharapkan menjadi multiplier effect bagi persoalan ekonomi di tengah-tengah masyarakat. Hanya saja banyak kalangan UKM yang mengeluhkan sulitnya mengakses pinjaman dari perbankan. Bisa karena persyaratan yang berat, berbelit ataupun suku bunga yang cukup tinggi.

${ }^{1}$ Mahasiswa M.Si. FEB UGM

${ }^{2}$ David B Audretsch dan Roy Thurik (2000), "Capitalism and Democracy in the $21^{\text {st }}$ Century: From the Managed to the Entrepreneurial Economy", Journal of Evolutionary Economics 10, pp. 17-34.

${ }^{3}$ Eduardus Christmas (2009), "Entrepreneurship Capital dan Pertumbuhan Manufaktur Regional Studi Empiris Provinsi Jawa Timur Tahun 2000-2005”, Skripsi FE UI. Tidak dipublikasikan. 
Ihda A Faiz: Ketahanan Kredit Perbankan Syariah...

Telah banyak studi yang membuktikan daya tahan sektor UKM menghadapi berbagai terpaan kesulitan ekonomi bahkan dalam masa resesi atau krisis. Akses kredit inilah yang menjadi harapan bagi UKM untuk mengembangkan usaha mereka. Terbukti sekitar 40 ribu pengusaha kecil mengalami peningkatan peringkat menjadi pengusaha kelas menengah tahun ini dengan memanfaatkan fasilitas Kredit Usaha Rakyat (KUR) yang disediakan oleh perbankan ${ }^{4}$. Efek peningkatan peringkat ini tentu saja akan sangat dirasakan dampaknya secara luas oleh masyarakat mengingat jumlah usaha kecil di Indonesia sangat banyak. Hingga saat ini jumlah pengusaha mikro, kecil dan menengah mencapai 53 juta orang. Bila dibandingkan dengan total pengusaha lain porsi mereka mencapai $90 \%$.

Penyaluran kredit kepada usaha sektor kecil atau menengah bagi kalangan perbankan menjadi solusi jangka panjang penyaluran kredit yang 'berkualitas'. Kredit kepada UKM, dengan pembinaan yang sesuai dan prospek ke depan yang cerah, menjadi penopang perbankan dari hantaman krisis sektor keuangan yang volatile. Meski tidak semenarik investasi di sektor keuangan, kredit UKM memiliki keunggulan tersendiri. Salah satunya keunggulan UKM adalah resisten terhadap gejolak krisis dan sangat potensial untuk melejit menjadi bentuk usaha baru yang tangguh. Keunggulan ini tentu saja akan berimbas pada kreditur yang menjadi mitra mereka bila didampingi dengan baik. Hanya saja perlu penanganan khusus memperlakukan sektor UKM agar menjadi mutiara yang bersinar nantinya.

Pola penyaluran kredit perbankan konvensional yang hanya sekedar menarik bunga menjadi keluhan kalangan UKM mengingat mereka juga butuh pendampingan, pengarahan bahkan sharing potensi (untung atau rugi). Hal yang berbeda dipraktikkan oleh kalangan perbankan syariah. Bank syariah tidak hanya sekedar menyalurkan kredit dengan tanpa memungut biaya (interest), karena hal ini dilarang oleh syara' (hukum Islam), tetapi turut serta mendampingi serta berbagi resiko dengan ' amil. Inilah yang menjadi keunggulan bank syariah.

Non Performing Loan (NPL) masih menjadi salah satu topik menarik dalam isu perbankan saat ini, utamanya setelah krisis sering menerpa dan semakin rentannya posisi perbankan dalam perekonomian konvensional yang menggelembung (bubbles economy) seperti sekarang. Selain sebagai salah satu indikator kesehatan perbankan, NPL juga bisa memberikan beberapa kandungan informasi terkait perkembangan sektor riil. Dari aspek pengelolaan perbankan, NPL dapat memberikan gambaran seberapa jauh manajer menjalankan pola pengelolaan kredit yang prudent. Kredit macet juga dapat menjadi indikator kelesuan sektor riil sebagai respon kondisi perekonomian secara umum. Bahkan dalam banyak penelitian, mulai dari prediksi bank gagal hingga indikator krisis ekonomi, tingkat NPL tak luput dari pengamatan.

${ }^{5}$ Koran Tempo, 17 September 2010. 
Ihda A Faiz: Ketahanan Kredit Perbankan Syariah...

Banyak kalangan yang posisinya sangat tergantung dengan keberadaan NPL. Seperti misalnya pemilik dana yang terancam tidak menerima return pasar dari capital mereka saat NPL yang tinggi. Para pemilik deposito yang tidak menerima return pasar dari deposito atau tabungan mereka karena bank membagi resiko kredit dengan menekan tingkat bunga deposito. Bahkan jika bank bangkrut, para deposan ini pun terancam akan kehilangan aset mereka apabila tidak terdapat sistem asuransi. Hingga seluruh pelaku ekonomi pun terancam terkena imbasnya bila krisis perbankan yang berawal dari kredit macet ini berubah menjadi krisis ekonomi. NPL dapat mengakibatkan jatuhnya sistem perbankan, mengerutnya pasar saham dan bahkan mengakibatkan kontraksi dalam perekonomian ${ }^{5}$. Tragedi krisis perbankan yang cukup pahit dalam sejarah dapat kita temui misalnya di Amerika Serikat tahun 1931, krisis perbankan di Nigeria (1945-1955), krisis perbankan di Inggris (1973-1874), krisis di Asia (1997-1998), bank run di Northern Rock (2007) dan runtuhnya Bear Stearns $(2008)^{6}$. Bahkan krisis di Yunani yang terjadi belum lama ini.

Kondisi tersebut semakin sering kita jumpai saat ini seiring semakin melesatnya pertumbuhan sektor moneter jauh meninggalkan sektor riil. Sektor perbankan tak pernah absen turut serta terseret dalam pusaran krisis baik sebagai pemicu ataupun korban. Bank syariah sebagai salah satu harapan baru bentuk sistem perbankan yang diklaim anti krisis menjadi fenomena menarik untuk diamati. Salah satu ciri khas sistem perbankan syariah yang membedakannya dengan bank konvensional adalah sistem bagi hasil atau profit and loss sharing (PLS) dan skema akad yang unik. Dengan mendasarkan pada skema PLS dan tidak menggunakan instrumen bunga (interest), kinerja bank syariah akan sangat dipengaruhi oleh faktor internal yaitu bagaimana pengelolaan kredit yang diberikan serta pola pendampingan kepada debitur. Perpaduan skim PLS dan akad dalam bank syariah akan memberikan porsi yang adil bagi kedua belah pihak yaitu distribusi keuntungan yang fair dan sharing resiko utamanya akad mudharabah. Pola semacam ini dinilai lebih berkeadilan dan menghindarkan perbankan dari pukulan resiko sektor keuangan dan suku bunga ${ }^{7}$.

Studi lebih lanjut tentang kondisi empiris untuk membuktikan berbagai asumsi yang dijelaskan sebelumny menjadi menarik melakukan karena berbagai alasan di atas.

${ }^{5}$ M.B. Hendrie Anto dan Desti Setyowati (2008), "The Indicatioan of Moral Hazard in Islamic Financing : A Comparative Study Between Islamic Bank and Conventional Bank in Indonesia 2003:1 - 2007:9", Paper Symposium "On Implementation of Islamic to Positive Economics in the World as Alternative of Conventional Economic System: Toward Development in the New Era of The Holistic Economics", Universitas Airlangga Surabaya 1-3 Agustus 2008.

${ }^{6}$ Ascarya (2009), "Pelajaran yang dapat dipetik dari Krisis Berulang: Perpektif Ekonomi Islam", Buletin Ekonomi Moneter dan Perbankan, Volume 12 Nomor 1 Juli 2009, pp. 33-82.

${ }^{7}$ Yunis Rahmawulan (2008), "Perbandingan Faktor Penyebab Timbulnya NPL dan NPF padaperbankan Konvensional dan Syariah di Indonesia”, Tesis Program Kajian Timur Tengah dan Islam Universitas Indonesia. 
Ihda A Faiz: Ketahanan Kredit Perbankan Syariah...

Penelitian ini mencoba mengungkap bagaimana pola pengelolaan kredit oleh kedua jenis perbankan di Indonesia serta reaksi kedua jenis perbankan tersebut atas krisis keuangan global yang terjadi tahun lalu.

\section{TINJAUAN PUSTAKA}

\section{A. Landasan Teori}

Terdapat beberapa variabel yang mempengaruhi perkembangan NPL pada perbankan, baik yang berasal dari internal maupun eksternal. Faktor internal biasanya berasal dari mekanisme corporate governance pihak perbankan, sedangkan faktor eksternal biasanya dipengaruhi oleh indikator makroekonomi. Berbagai faktor internal dan eksternal tersebut akan diakomodir dalam penelitian ini untuk melihat perilaku yang secara signifikan mempengaruhi NPL perbankan.

Keberadaan bunga sangat mempengaruhi kemampuan nasabah untuk melunasi kreditnya. Ketika terjadi kenaikan suku bunga, maka imbasnya adalah para pengusaha akan kesulitan mengembalikan kredit yang diambilnya dari perbankan. Fenomena NPL ini dalam sistem perbankan konvensional dapat kita amati dari pergerakan suku bunga yang ditetapkan pihak bank. Keduanya mempunyai hubungan yang saling berlawanan.

Kelancaran pelunasan kredit juga dipengaruhi oleh tingkat pendapatan masyarakat. Semakin tinggi tingkat pendapatan masyarakat yang dicerminkan oleh GDP, maka kemungkinan terjadinya kredit macet akan kecil. Begitu juga sebaliknya. Karena itu variabel GDP juga perlu diikutsertakan untuk mengamati perilaku NPL perbankan. Penelitian Kittikulsingh menunjukkan bahwa pada pertumbuhan GDP kurang dari 10\% setengah dari pinjaman akan macet dan total ekuitas dari sistem bank akan menghilang. Bila kondisi GDP cukup bagus (dan cenderung naik) tetapi tingkat NPL tinggi maka dapat disimpulkan terjadi mismanagement pihak perbankan dalam menyalurkan kredit ${ }^{8}$.

Kantor Pengawas Mata Uang Amerika Serikat atau Office of the Comptroller of the Currency melakukan studi tentang karakteristik perbankan yang mengalamikegagalan selama tahun 1980an di Amerika Serikat. Temuan utamanya adalah karena kualitas aset bank yang buruk. Sedang penentu kualitas aset merupakan tanggung jawab dari manager bank. Sebab lain yang mempengaruhi kegagalan bank adalah kebijakan kredit yang salah, sistem kontrol dan monitoring yang lemah, ketidakmampuan identifikasi awal NPL dan pemusatan konsentrasi kewenangan?

\footnotetext{
${ }^{8}$ Suthep Kittikulsingh (1999), "Non Performing Loans (NPLs): The Borrower's Viewpoint", TDRI Quarterly Review, Vol. 14, No. 4, Desember 1999, pp. 19-30.

${ }^{9}$ Office of the Comptroller of the Currency (1988), "Bank Failure an Evaluation of the Factors Contributing to the Failure of National Banks", dikutip dari www.occ.gov/static/publications/ bankfailure.pdf diakses 1 Juni 2010.
} 
Ihda A Faiz: Ketahanan Kredit Perbankan Syariah...

Faktor penentu tingkat NPL yang berasal dari internal institusi misalnya dapat kita amati dari pertumbuhan tingkat kredit (Loan to Deposti Ratio/LDR). Kaitannya dengan bank gagal (bank's failure) Honohan dan James menyatakan tingginya rasio NPL merupakan salah satu indikator penting disamping LDR, penentuan resiko yang keliru, dan ketidakmampuan bank mengantisipasi berbagai resiko yang dihadapi ${ }^{10}$. Agak sulit memposisikan indikator LDR di perbankan saat ini. Bila LDR dilakukan secara masif bisa mengakibatkan meningkatnya resiko kredit macet, tetapi bila tingkat LDR rendah maka sektor riil juga tidak akan berkembang.

Saat ini kondisi makroekonomi justru seringkali lebih berperan sebagai pemicu terjadinya kredit macet, yang berimbas pada krisis lebih kompleks. Krisis yang terjadi kini dapat mengambil banyak bentuk, mulai dari kesulitan keuangan (financial distress), banking rush, jatuhnya pasar saham, jatuhnya nilai mata uang, kesulitan neraca pembayaran, kegagalan pelunasan utang pemerintah, meledaknya financial bubbles ataupun kombinasi dari kesemuanya ${ }^{11}$. Saat ini banyak kalangan menilai perbankan merupakan institusi yang sangat riskan terkena krisis. Faktor makro yang kerapkali menyebabkan krisis perbankan diantaranya tingginya inflasi, fluktuasi tingkat suku bunga, volatilitas arus modal luar negeri (foreign capital flows) dan nilai tukar ${ }^{12}$. Berangkat dari sinilah beberapa indikator makroekonomi tersebut akan dimasukkan dalam variabel pengamatan.

\section{B. Penelitian Terdahulu}

Belum banyak penelitian yang mengungkap perbedaan respon antara bank syariah dan bank konvensional ditinjau dari aspek daya tahan terhadap hantaman krisis, apalagi yang mengungkap perbedaan besaran tingkat kredit macet di perbankan syariah terkait isu krisis keuangan global. Penelitian yang telah ada terkait tema ini sebagian besar membahas tentang stabilitas perbankan syariah atau tentang NPL berkaitan denga faktor pembentuknya. Èihák dan Hesse meneliti tentang perbedaan stabilitas perbankan syariah dan konvensional dari 20 sistem perbankan (negara) selama tahun 1993-2004. Penelitian ini menyimpulkan tiga temuan yaitu pertama, bank islam kecil (aset kurang dari US\$ 1 milyar) cenderung lebih kuat secara finansial dibanding bank komersial kecil. Kedua, bank komersial besar cenderung lebih kuat finansialnya dibanding bank islam besar. Ketiga, bank islam kecil cenderung lebih kuat finansialnya dibanding bank komersial besar. Kekuatan finansial disini mencerminkan stabilitas keuangan yang dimiliki bank tersebut. Selain itu penelitian ini juga menunjukkan bahwa

${ }^{10}$ J.F. Honohan dan C. James (1997), "Banking System Failures In Developing And Transition Countries: Diagnosis And Predictions", BIS Working Paper 39.

${ }^{11}$ Ascarya (2009), ibid.

${ }^{12}$ Christophe J. Godlewski (2004), "Excess Credit Risk and Bank's Default Risk: An Application of Default Prediction's Models to Banks from Emerging Market Economics", Financial Economics and Financial Econometrics. 
Ihda A Faiz: Ketahanan Kredit Perbankan Syariah...

market share dari bank islam tidak mempunyai pengaruh signifikan terhadap kekuatan finansial bank yang lain. Dari 75 negara yang terdapat bank syariah, penelitian ini melibatkan 77 bank islam dan 397 bank komersial. ${ }^{13}$

Terdapat dua metode analisis data yang digunakan yaitu untuk mengukur stabilitas bank dengan metode Z Score dan analisis regresi (OLS) untuk melihat faktorfaktor yang mempengaruhi stabilitas tersebut. Kecenderungan bank syariah yang lebih stabil pada ukuran aset kecil dibanding aset besar menurut penelitian ini kemungkinan disebabkan oleh kompleksitas mekanisme kerja bank syariah dalam menyalurkan kredit. Kredit merupakan salah satu 'barang dagangan' utama bank syariah dalam pengelolaan diversifikasi resiko karena Islam melarang berinvestasi di sektor yang mengandung unsur judi (maysir). Dengan berbasis sistem kerja bagi hasil (PLS), bank syariah dituntut untuk melakukan monitoring dan pendampingan lebih ketat terhadap kredit yang diberikan untuk menghindari credit risk. Keterbatasan pola dan jenis pengelolaan resiko ini mengakibatkan cost dan kerumitan bank syariah menjadi lebih besar jika aset yang dimiliki semakin besar. Hanya saja bila kondisi ini tidak ditangani dengan tepat (prudent) akan muncul kecenderungan adverse selection dan moral hazard.

Pernyataan ini didukung oleh hasil penelitian Choong dan Liu yang mengungkap adanya deviasi (penyimpangan) bank syariah antara konsep PLS dan temuan lapangan ${ }^{14}$. Dua kemungkinan penyebabnya yaitu konsep pendanaan PLS dihadapkan pada problem agency theory dan ketidakmampuan pihak manajemen mengelola pola pembiayaan berbasis bagi hasil. Penelitian ini juga mencatatkan beberapa hal penting belum ter-cover seperti data laporan keuangan yang digunakan sebagian masih unconsolidated serta tidak mengikutkan perbankan syariah sistem 'windowes' dengan bank konvensional ataupun office channeling, atau karena rendahnya Islamic corporate identity sehingga stakeholder sulit membedakan dan mengawasiny $\mathrm{a}^{15}$.

Penelitian berikutnya dilakukan oleh Boumediene dan Caby yang melakukan penelitian tentang perbankan syariah dengan isu yang sama yaitu stabilitas. Berangkat dari teori perbankan syariah yang lebih mengedepankan aspek intermediary dengan sektor riil dibandingkan sekedar mendapatkan laba dengan model-model spekulatif, penelitian ini mencoba melihat stabilitas perbankan syariah di saat terjadi krisis keuangan global (subprime crisis). Dengan mengambil sampel sebanyak 14 bank syariah dan konvensional, penelitian ini menggunakan pendekatan conditional variance(volatility) return untuk mengukur stabilitas perbankan. ${ }^{16}$

${ }^{13}$ Martin Ėihák dan Heiko Hesse (2008), "Islamic Bank and Financial Stability: An Empirical Analysis”, IMF Working Paper, WP/08/16, Januari 2008.

${ }^{14}$ Beng Soon Choong dan Ming-Hua Liu (2008), "Islamic Banking: Interest-Free or InterestBased?", dikutip dari http://ssrn.com/abstract=868567 diakses 1 Juni 2010.

${ }^{15}$ Roszaini Haniffa dan Mohammad Hudaib (2007), "Exploring the Ethical Identity of Islamic Banks via Communication in Annual Reports", Journal of Business Ethics 76, pp. 97-116.

${ }^{16}$ Aniss Boumediene dan Jerome Caby (2010), "The Stablity of Islamic Banks During Subprime Crisis", dikutip dari http://ssrn.com/abstract=1524775, diakses 11 Agustus 2010. 
Ihda A Faiz: Ketahanan Kredit Perbankan Syariah...

Hasil penelitian ini menunjukkan bahwa return bank konvensional lebih tinggi volatilitasnya saat terjadi krisis dibanding bank syariah. Perbankan syariah pada awalnya menunjukkan volatilitas yang rendah (stabil) tetapi cenderung naik saat terjadi krisis melalui mekanisme moderate extent. Melalui pendekatan metode Generailzed Autoregressive Conditional Heteroskedasticity (GARCH) penelitian ini memperkuat hipotesis bahwa bank Islam cenderung lebih tahan (immune) terhadap gejolak krisis subprime mortgage serta menunjukkan bahwa bank Islam bukanlah subyek spekulasi yang mengakibatkan krisis sebagaimana bank konvensional. Tetapi penelitian ini tidak menafikan bahwa bank syariah pada akhirnya terkena juga imbas krisis subprime mortgage melalui mekanisme sektor riil karena imbas krisis yang mengakibatkan kelesuan perekonomian secara umum. ${ }^{17} \mathrm{Hal}$ ini bisa dimengerti mengingat operasionalisasi bank syariah sangat tergantung pada kinerja sektor riil (sebagaimana konsep profit and loss sharing/PLS) sehingga apabila sektor riil mengalami kelesuan maka bank syariah juga akan terkena dampaknya. Kondisi ini tentu saja berbeda dengan bank konvensional (berbasis bunga/ interest) yang juga banyak bergantung pada pengambilan resiko di financial market. Artinya dari penelitian ini dapat pula kita simpulkan jika bank konvensional turut pula berperan dalam penciptaan krisis maka bank syariah lebih sebagai korban gelombang krisis keuangan global.

Faiz menemukan bahwa untuk kasus Indonesia stabilitas perbankan syariah dipengaruhi oleh besarnya pembiayaan (LDR), jumlah aset yang dimiliki dan aspek banking share. Sedangkan bank konvensional stabilitasnya hanya dipengaruhi oleh income diversity yang menggambarkan diversifikasi produk yang diberikan dan besarnya ketergantungan pada pendapatan bunga (interest). Sedangkan secara keseluruhan sistem perbankan di Indonesia stabilitasnya dipengaruhi oleh besarnya pembiayaan, tingkat efisiensi, jumlah aset, income diversity, nilai tukar dan pertumbuhan PDB. ${ }^{18}$

Terdapat hubungan antara sistem perbankan, pasar real estate dan non performing loan (NPL) sebagaimana ditunjukkan dalam penelitian Wu dan Selvili. ${ }^{19}$ Jika kondisi makroekonomi, pasar real estate dan kebijakan penyaluran kredit baik maka posisi NPL akan aman. Begitu juga sebaliknya. Tetapi apabila ditemukan NPL meningkat sedang faktor yang lain mendukung berarti kemacetan lebih disebabkan oleh risky lending behavior akibat perbankan tidak hati-hati dalam menyalurkan kredit. Kondisi ini juga mengindikasikan terjadinya moral hazard di perbankan. Tingkat NPL dari sisi internal dipengaruhi oleh bagaimana pengelolaan kredit yang dilakukan oleh perbankan, selain ditentukan pula oleh proses screening objek kredit yang tepat.

\footnotetext{
${ }^{17}$ ibid.

${ }^{18}$ Ihda A. Faiz (2010), “Analisis Stabilitas Perbankan Syariab di Indonesia dan Faktor Yang Mempengarubinya", Jurnal Ekonomi dan Bisnis Islam (Ekbisi). Forthcoming.

${ }^{19}$ Chang Wu dan Selvili (2003), "Banking System, Real Estate Markets and Non Performing Loans”, International Real Estate Review, Vol 6 No 1, pp. 43-62.
} 
Ihda A Faiz: Ketahanan Kredit Perbankan Syariah...

Meskipun memiliki peluang pengembangan usaha yang prospektif, sektor UKM memerlukan pembinaan dan pendampingan yang intens. Kelebihan sektor ini biasanya lebih taat bayar dan tahan terhadap guncangan krisis. Namun bila bank hanya sekedar menyalurkan pinjaman (take and give) kredit sektor UKM justru bisa menjadi bumerang. Kondisi ini ditemukan oleh Lu dan $\mathrm{Hu}$ yang menemukan bahwa pemberian kredit yang berlebih (eksesif) kepada perusahaan daerah membuka peluang kenaikan NPL. Selain itu juga dipengaruhi oleh faktor tambahan pemberian kredit kepada perusahaan-perusahaan yang mengalami kesulitan keuangan. Kondisi ini dapat kita lihat dari kondisi dan porsi LDR (Loan to Deposit Ratio) perbankan. LDR selain berpeluang meningkatkan stabilitas perbankan jangka panjang (terutama hadangan krisis) dapat pula menjadi beban (macet) bila tidak ditangani dengan baik. ${ }^{20}$

Godlewski melakukan penelitan tentang pola pengambilan kredit beresiko (credit excessive risk) di negara berkembang dan potensi kegagalan bank (bank's default). Penelitian ini menunjukkan bahwa tipe lingkungan akan sangat mempengaruhi imbas kredit berlebih, utamanya faktor peraturan perbankan, taat asas dan kualitas penegakan hukum. Beberapa hal yang akan mengurangi resiko bank gagal diantaranya adalah keberadaan sistem asuransi deposit, frekuensi evaluasi dan monitoring serta penegakan hukum. ${ }^{21}$

\section{METODE PENELITIAN}

\section{A. Deskripsi Data}

Sumber rujukan data yang digunakan dalam penelitian ini berasal dari publikasi Statistik Perbankan Indonesia dan Statistik Perbankan Syariah dari Bank Indonesia serta beberapa data makroekonomi yang berasal dari Badan Pusat Statistik (BPS). Data perbankan syariah yang digunakan terdiri dari Bank Umum Syariah dan Unit UsahaSyariah sedang perbankan umum diambil secara agregat. Laporan dari BI dianggap telah mengakomodir seluruh perbankan (baik syariah ataupun konvensional). Hanya saja dalam perjalanannya terdapat data yang tidak lengkap terutama pada perbankan syariah. Namun hal itu dapat teratasi dengan beberapa hal, misal desain penelitian yang cukup simpel dan berbagai informasi yang didapatkan dari publikasi lain. Penelitian ini mengambil periode pengamatan dari tahun 2003 kuartal I hingga 2010 kuartal I dengan data yang berperiode kuartalan.

\section{B. Variabel dan Definisi Operasional}

Variabel yang digunakan dalam penelitian ini mencakup beberapa komponen yang dianggap mewakili indikator makroekonomi dan representasi internal dalam penyaluran kredit. Variabel makroekonomi yang digunakan adalah inflasi (INF),

${ }^{20}$ Shandre Ding Lu dan Qing Hu (2001), “The Link Between Behaviour And Non Performing Loan In China", Internet

${ }^{21}$ Christophe J. Godlewski (2004), “Excess...”, ibid. 
Ihda A Faiz: Ketahanan Kredit Perbankan Syariah...

Sertifikat Bank Indonesia (SBI), Sertifikat Wadiah Bank Indonesia (SWBI), Gross Domestik Product (GDP), dan nilai tukar rupiah terhadap US dolar (EXR). Sedangkan variabel internal mencakup Non Performing Loan (NPL) untuk bank konvensional, Non Performing Financing (NPF) untuk bank syariah dan besarnya kredit yaitu LOAN untuk bank konvensional dan FIN untuk bank syariah. Sedangkan untuk mengamati perilaku perbedaan reespon perbankan atas krisis finansial global digunakan variabel dummy dengan cut off tanggal 18 Juli 2007 sewaktu Bear Stearns mengumumkan dua hedge funds-nya mengalami kerugian besar sebesar US\$1,5 miliar ${ }^{22}$.

\section{Model Penelitian}

Pengujian dan pembahasan dalam penelitian ini dibagi menjadi dua bagian metode yaitu Vector Auto Regression (VAR) dan regresi berganda atau Ordinary Least Square (OLS). VAR adalah persamaan n-dengan variabel endogen n-, dimana setiap variabel dijelaskan oleh lag-nya sendiri, serta nilai sekarang dan nilai dulu dari variabel endogen lainnya dalam model. Model VAR banyak digunakan karena mampu menangkap hubungan dinamis antar variabel-variabel pengamatan yang tidak terbatas pada suatu waktu yang sama tetapi terus berlanjut sepanjang waktu. Model ini juga bersifat dinamis dan simultan sehingga kita dapat menganalisa efek yang terjadi pada variabel endogen karena adanya shock variabel endogen lain dari waktu ke waktu. Mekanisme secamam ini dapat ditelusuri melalui analisa impulse response function (IRF) yang memungkinkan peneliti untuk menganalisa hubungan berantai yang terjadi antarvariabel.

VAR dianggap sebagai deret waktu multivariat yang memperlakukan semua variabel secara endogen karena tidak ada keyakinan bahwa variabel memang benar eksogen sehingga memungkinkan bagi kita untuk melihat apa yang sebenarnya terjadi ${ }^{23}$. Metode ini dapat menghindarkan dari bias parameter karena mengesampingkan variabel yang relevan serta bebas dari batasan berbagai teori ekonomi yang sering muncul ${ }^{24}$. Jika memang terjadi simultanitas murni antar himpunan variabel, semuanya harus diperlakukan dengan setara dan tidak boleh ada perbedaan apriori apapun antara variabel endogen dan eksogen ${ }^{25}$. Model matematis VAR dapat digambarkan sebagai berikut:

$$
x_{t}=\mu_{t}+\sum_{i=1}^{k} A_{i}+X_{t-1}+\varepsilon_{t}
$$

${ }^{22}$ Aniss Boumediene dan Jerome Caby (2010), “The Stablity...”, ibid.

${ }^{23}$ Ascarya (2009), ibid.

${ }^{24}$ Damodar N. Gujarati (2003), Basic Econometrics, Fourth Edition-International Edition, Singapore: McGraw Hill, p. 848.

${ }^{25}$ C. A. Sims (1980), "Macroeconomics and Reality", Econometrica, Vol. 48, 1980, pp. 1-48, dikutip dalam Damodar N. Gujarati (2003), Basic..., ibid. 
Ihda A Faiz: Ketahanan Kredit Perbankan Syariah...

Dimana $x_{t}$ adalah vektor variabel endogen dengan dimensi ( $\left.\mathrm{n} \times 1\right), \mu_{t}$ adalah vektor variabel eksogen termasuk konstanta (intercept) dan trend, $A_{i}$ adalah matriks koefisien dengan dimensi $(\mathrm{n} \times \mathrm{n})$ dan $\varepsilon_{t}$ adalah vektor residual. Sedangkan untuk model VAR dengan sistem primitif bivariat orde pertama sederhana sebagaimana dirumuskan oleh Enders ${ }^{26}$ adalah sebagai berikut:

$$
\begin{aligned}
& y_{t}=b_{10}-b_{1 \mathbf{z}} z_{t}+\gamma_{1 \mathbf{1}} y_{t-1}+\gamma_{1 \mathbf{z}} z_{t-1}+\varepsilon_{y t} \\
& z_{t}=b_{20}-b_{2 \mathbf{1}} y_{t}+\gamma_{2 \mathbf{1}} y_{t-1}+\gamma_{2 \mathbf{z}} z_{t-1}+\varepsilon_{z t}
\end{aligned}
$$

Model di atas diasumsikan baik $y_{t}$ maupun $z_{t}$ adalah statis, $\varepsilon_{y t}$ dan $\varepsilon_{z t}$ adalah white noise disturbance dengan deviasi standar $\sigma_{y}$ dan $\sigma_{z}$ dan dan adalah white noise disturbance yang tidak berkorelasi. Dalam model bivariat sederhana dan dipengaruhi oleh sekarang dan dulu, sementara dipengaruhi oleh sekarang dan dulu.

VAR memberikan empat alat analisis yaitu peramalan (forecasting), impulseresponsefunction (IRF), forecasterrorvariancedecomposition (FEVD) dan uji kausalitas Granger. Layaknya pemodelan ekonometri lainnya, VAR juga harus melalui serangkaian proses spesifikasi dan identifikasi model. Spesifikasi model meliputi pemilihan variabel dan panjang lag yang akan digunakan dalam model. Sedangkan identifikasi model digunakan untuk mengidentifikasi persamaan sebelum dapat digunakan sebagai perkiraan. Beberapa pengujian yang dilakukan antara lain dijelaskan berikut ini.

\section{Uji Stasioneritas}

Asumsi utama yang melandasi pemodelan VAR adalah data stasioner. Suatu pengujian deret waktu (time series) dikatakan stasioner apabila data tersebut memiliki rerata (mean), variance (varians) dan autocovariance yang sama pada setiap titik dimanapun dilakukan analisa data pada periode tersebut (time invariant). Dengan demikian data akan berfluktuasi di sekitar rata-ratanya dan cenderung kembali ke arah rata-ratanya (mean reversion). Jika data tidak memenuhi kriteria ini maka pengujian akan menghasilkan spurrious regression (regresi lancung) yang menyesatkan. Deret waktu yang tidak stasioner berarti data tersebut memiliki time varying mean atau time varying variance atau keduaduanya. Uji stasioneritas ini akan meningkatkan akurasi dan analisis VAR ${ }^{27}$. Terlebih dalam kaitannya dengan proses peramalan (forecasting), maka data yang digunakan disyaratkan telah stasioner.

Terdapat beberapa metode pengujian VAR diantaranya adalah uji akar unit (unit root tests). Jika data yang digunakan statis pada levelnya maka VAR dapat dilakukan pada level tersebut. Namun jika data tidak statis maka data akan mengalami serangkaian proses perlakuan yang berbeda. Menurut Ascarya jika datanya statis pada perbedaan

${ }^{26}$ Walter Enders (2004), Applied Econometric Time Series, New York: John Wiley and Sons, Inc., hal. 294 sebagaimana dikutip dalam Ascarya (2009), ibid.

${ }^{27}$ Yonathan S. Hadi (2003), “Analisis Vector Auto Regression (VAR) Terhadap Korelasi Antara Pendapatan Nasional dan Investasi Pemerintah Indonesia, 1983/1984 - 1999/2000", Jurnal Keuangan dan Moneter, Volume 6 Nomor 2. 
Ihda A Faiz: Ketahanan Kredit Perbankan Syariah...

awal (first difference) maka harus diperiksa keberadaan kointegrasi antar variabel. Jika data tidak dikointegrasikan maka VAR dapat dilakukan dengan perbedaan awal, dan hal itu hanya dapat memperkirakan hubungan jangka pendek antar variabel. Tetapi jika data dikointegrasikan maka digunakan metode Vector Error Correction Model (VECM) untuk mengatasi kelemahan VAR pada perbedaan awal sehingga dapat diperoleh gambaran hasil hubungan jangka panjang antar variabel..$^{28}$

Metode yang digunakan dalam pengujian unit akar ini adalah uji Augmented Dickey-Fuller (ADF) dan uji Phillips-Perron (PP). Sedangkan nilai kritisnya digunakan kriteria nilai kritis yang diungkapkan oleh MacKinnon. Jika nilai t-ADF atau t-PP lebih dari nilaikritis yang dipersyaratkan maka data itu statis atau tidak memiliki akar unit.

\section{Pemilihan Lag Optimal}

Permasalahan utama dalam data time series adalah adanya autokorelasi. Untuk mengatasi permasalahan ini maka harus digunakan panjang lag optimal yang diperoleh dari pengujian panjang lag optimal. Penentuan panjang lag optimal dalam penelitian ini didasarkan pada lag terpendek menurut Schwarz Information Criterion (SIC). Menurut Gujarati SIC memberikan timbangan yang lebih baik daripada AIC karena SC memberi timbangan lebih besar dan penalti lebih terhadap penambahan variabel ${ }^{29}$.

\section{Uji Kointegrasi}

Jika variabel dalam tahap dasar (level) tidak stasioner maka data tersebut harus memenuhi kriteria proses integrasi untuk mendapatkan hubungan jangka panjang. Beberapa kalangan menolak proses stasionerisasi (misal dengan metode differencing dan detrending) karena akan mengurangi bahkan menghilangkan informasi tentang pergerakan data dari variabel model. Namun ditinjau dari segi peramalan model VAR padafirst differences akanlebih akurat dibanding VAR dalam levels. Bilaterdapat kointegrasi pada variabel maka penggunaan VAR dalam $1^{\text {st }}$ difference akan mengakibatkan misspesifikasi ${ }^{30}$.

\section{Uji Stabilitas}

Kita dapat menggunakan uji stabilitas untuk menentukan stabil atau tidaknya suatu estimasi. VAR pada lag optimal harus stabil karena jika tidak akan menghasilkan Impulse Response Functioan dan Forecast Error Variance Decomposition (FEVD) menjadi tidak valid. IRF digunakan untuk menentukan respon dari satu vaiabel endogen dari guncangan variabel lain dalam model tersebut. Sedang FEVD digunakan untuk menentukan kontribusi relatif dari satu variabel untuk menjelaskan variabilitas dari variabel endogen ${ }^{31}$. Untuk itu kita dapat mengamati dari nilai modulus atau unit lingkaran. Dikatakan stasioner bila nilai modulus kurang dari 1.

${ }^{28}$ Ascarya (2009), ibid.

${ }^{29}$ Damodar N. Gujarati (2003), Basic..., p.538.

${ }^{30}$ Rizal Adi Prima (2004), "Disparitas Efek Regional dan Faktor Penentu Transmisi Kebijakan Moneter Daerah : Kasus Sumatra-Jawa”, Skripsi Fakultas Ekonomi Universitas Indonesia, tidak dipublikas ikan.

${ }^{31}$ Ascarya (2009), ibid. 
Ihda A Faiz: Ketahanan Kredit Perbankan Syariah...

\section{Regresi Berganda}

Selain pengamatan menggunakan VAR, analisis penelitian ini juga menggunakan regresi linier berganda untuk melihat respon beberapa variabel yang terpilih secara bersama-sama atas NPL/NPF. Selain itu, penggunaan regresi berganda juga ditujukan untuk menguji pengaruh krisis perekonomian global terhadap NPL/ NPF yang diberikan perbankan Indonesia. Data dalam metode ini pun mengalami beberapa tahapan pengujian asumsi klasik. Sedang untuk tetap mendapatkan kandungan informasi dan karakteristik data maka dalam persamaan regresi berganda ini digunakan data tingkat level.

$$
\begin{array}{ll}
\text { NPL(NPF) }= & \alpha_{t}+\beta_{t} M E I_{t}+\delta_{t} I B I_{t}+\gamma_{t} D_{t}+\varepsilon_{t} \\
\text { Dimana } & \\
N P L(N P F)= & \text { besarnya rasio kredit/pembiayaan macet } \\
M E I_{t} & \text { macro economics indicator adalah variabel makroekonomi } \\
& \text { negara (Inflasi, nilai tukar, SBI/SWBI dan pertumbuhan PDB) } \\
= & \text { internal banking indicator yaitu variabel struktur dan } \\
& \text { perkembangan perbankan (besarnya kredit yang diberikan dan } \\
& \text { Loan to Deposit Ratio/LDR) } \\
= & \text { variabel dummy } \\
D & =\text { konstanta } \\
\alpha_{t} \beta_{t} \delta_{t} \gamma_{t} & \text { standar error } \\
\varepsilon_{t} &
\end{array}
$$

\section{HASIL DN PEMBAHASAN}

\section{A. Model VAR}

Semua variabel penting yang terlibat dalam pembahasan teori sebelumnya diuji stasioneritasnya. Berdasakan tabel 1 dapat kita lihat hampir semua variabel stasioner dalam tahap level, kecuali NPL, SBI, LDR dan INF yang stasioner dalam tahap perbedaan awal (first difference). Setelah didapatkan variabel yang stasioner maka dilakukan pengujian signifikansi hubungan antara variabel independen dan variabel dependen. Dari berbagai kemungkinan pengujian yang telah dilakukan didapatkan variabel independen yang signifikan berhubungan dengan variabel dependen. Untuk perbankan konvensional, variabel INF, SBI dan LDR adalah variabel yang signifikan berhubungan dengan NPL. Sedangkan LOAN, GDP dan INF tidak signifikan berpengaruh terhadap NPL. Terpilihnya variabel tersebut kemungkinan dikarenakan kesamaan tingkat stasioneritas dalam $1^{\text {st }}$ difference. Sedangkan dalam model bank syariah 
Ihda A Faiz: Ketahanan Kredit Perbankan Syariah...

variabel yang signifikan berhubungan dengan NPF adalah FIN, GDP dan EXR. Secara mengejutkan ternyata variabel SWBI tidak cukup signifikan mempengaruhi NPF. Sedang variabel EXR yang dalam penelitian Rahmawulan tidak signifikan ${ }^{32}$, dalam penelitian ini menunjukkan hubungan yang signifikan (tingkat 10\%). Semua variabel yang berhubungan signifikan tersebut kemudian dimasukkan sebagai variabel endogen dalam persamaan VAR.

Panjang lag optimal yang diperoleh dari pengujian digunakan untuk menghindari permasalahan autokorelasi dalam time series. Berdasarkan pengujian menurut kriteria Schwarz Information Criterion (SC) dalam tabel 2 dan 3 didapatkan hasil untuk perbankan syariah panjang lag optimal adalah tingkat level karena semua variabel yang terlibat telah stasioner pada tingkat level. Sedangkan dari hasil uji SC perbankan konvensional panjang lag optimal berada pada lag 1.

Pengujian stabilitas dapat dilakukan melalui VAR stability condition check berupa roots of characteristic polynomial terhadap seluruh variabel yang digunakan dikalikan dengan jumlah lag dari masing-masing variabel. Tabel 4 dan 5 menunjukkan kedua jenis perbankan kesemuanya memiliki nilai absolut root unit dengan modulus kurang dari satu. Kedua jenis perbankan stabil hingga lag 4. Dari uji ini menunjukkan stabilitas estimasi VAR maka dapat dilakukan langkah pengamatan Impulse Response Function (IRF). Hanya saja uji stasioneritas menurut Johansen terhadap NPL sebagaimana disajikan dalam tabel 7, menunjukkan tidak terdapat kointegrasi dengan variabel sehingga tidak terdapat hubungan jangka panjang. Sedangkan pengujian Stasioneritas Johansen terhadap NPF yang ditampilkan pada tabel 6 menunjukkan tiga persamaan kointegrasi pada nilai kritis yang ditentukan. Uji kointegrasi dapat juga dilakukan dengan melakukan regresi berganda variabel dependen dengan residual variabel yang belum stasioner tingkat level. Dengan metode inipun menunjukkan hasil yang serupa.

Hasil pengujian IRF menunjukkan hasil yang sesuai perumusan teori. Besarnya NPF dalam perbankan syariah ternyata dipengaruhi oleh FIN yang bertanda negatif dengan puncak terendah sebesar -0.003669 . Artinya semakin besar pembiayaan syariah yang diberikan akan menurunkan tingkat NPF. Hubungan NPF dengan GDP juga bertanda negatif dengan nilai terendah sebesar -0.003125 yang berarti semakin tinggi tingkat pendapatan masyarakat akan menurunkan besarnya NPF. Sedangkan faktor nilai tukar bertanda negatif yaitu -0.000121 meski tidak cukup signifikan. Semua guncangan maksimal terjadi pada periode ke 1 . Hubungan NPL dan INF pada perbankan konvensional bertanda positif dengan guncangan sebesar 0.001737 pada periode ke 5 . Ini berarti semakin tinggi inflasi yang terjadi di masyarakat akan meningkatkan kredit macet. Hubungan NPL dengan LDR bertanda negatif dengan nilai -0.002396 yang terjadi pada periode ke 2 . Hal ini berarti tingginya LDR tidak akan membawa konsekuensi besarnya kredit macet seperti apa yang sering

${ }^{32}$ Yunis Rahmawulan (2008), "Perbandingan..., ibid. 
Ihda A Faiz: Ketahanan Kredit Perbankan Syariah...

dikhawatirkan oleh banyak kalangan perbankan. Tetapi justru pada faktanya banyak perbankan yang tidak 'bergegas' menjalankan fungsi intermediasinya ini dengan indikasi rendahnya kucuran dana kredit hingga pertengahan tahun ini

Sedangkan tingkat SBI berhubungan negatif dengan NPL sebesar -0.000123 tetapi tidak cukup signifikan dan pengaruhnya berlangsung cukup lama yakni puncaknya pada periode ke 8 . Temuan ini cukup menjadi alasan untuk kasus Indonesia terkait penetapan suku bunga (interest rate) oleh Bank Sentral yang tidak cukup membawa pengaruh yang signifikan terhadap pergerakan indikator perekonomian nasional. Kondisi semacam ini terjadi karena lemahnya regulasi dan pengawasan dari Bank Sentral atas perilaku perbankan yang masih menerapkan spread margin yang cukup tinggi. Kebijakan Bank Indonesia yang menurunkan acuan tingkat suku bunga ternyata tidak menjadikan para bankir menurunkan tingkat kredit pinjaman mereka sehingga kebijakan ini tidak berdampak pada sektor riil. Perbankan syariah justru tidak terpengaruh NPL-nya dengan berbagai variabel makro seperti yang diungkap. Justru ketika pendapatan masyarakat meningkat bank syariah mendapatkan keuntungan dengan semakin menurunnya tingkat kredit macet.

Terjadinya krisis keuangan global yang seringkali melalui mekanisme makro ekonomi dapat dihindari perbankan syariah dengan tidak bergantungnya bank syariah pada instrumen global. Dalam pengamatan menggunakan Forecast Error Variance Decomposition (FEVD) terhadap kedua jenis perbankan, terlihat tingkat NPL/NPF masingmasing bank sangat dipengaruhi oleh lag NPL/NPF sendiri pada periode sebelumnya. Hal ini dapat diartikan besarnya kredit macet yang akan dihadapi oleh perbankan akan sangat tergantung pada skema dan model pemberian kredit yang digunakan serta kontrol atasnya. Dalam hal ini pembedaan jenis kredit macet bank syariah (NPF) dan konvensional (NPL) dapat digunakan sebagai komparasi pengaruh perbedaan pemakaian model penyaluran kredit atas aspek potensi kredit macet masa datang.

\section{B. Regresi Berganda}

Hasil pengujian model dengan regresi berganda tersaji dalam tabel 8 dan 9 untuk perbankan syariah dan konvensional. Kedua jenis model perbankan telah melalui serangkaian pengujian asumsi klasik, yaitu uji normalitas, multikolinieritas, heterokedastisitas dan autokorelasi. Untuk perbankan syariah model yang diajukan telah memenuhi syarat (lolos uji) asumsi klasik dan didapatkan komposisi model terbaik dari berbagai kemungkinan. Sedangkan model perbankan konvensional masih terkendala multikolinieritas. Berbagai treatment pun telah dilakukan, baik dengan mengubah ke bentuk log ataupun mengkombinasikan berbagai variabel yang memungkinkan terjadinya misspecification. Tetapi tidak dapat menyembuhkan permasalahan ini. Hanya saja dari model yang diajukan paling tidak hasil koefisien regresi masih konsisten serta tidak bias. Tetapi memang varians dari distribusi koefisien

regresi menjadi tidak efisien. Model OLS tidak lagi yang terbaik (no longer best) meski 
Ihda A Faiz: Ketahanan Kredit Perbankan Syariah...

sudah linier dan unbiased (LUE). Dampaknya adalah perhitungan standard error metode OLS tidak dipercaya sehingga uji estimasi yang didasarkan pada distribusi t ataupun $F$ tidak lagi bisa dijadikan evaluasi hasil regresi. Kondisi ini bisa kita lihat dalam persamaan NPL yang menunjukkan tidak signifikannya variabel INF.

Karena dalam pemodelan ini tidak berusaha mencari prediksi maka hasil yang ada dianggap sudah mencukupi penilaian atas jawaban pertanyaan yang diajukan. Terutama kaitannya dengan pengamatan respon pengaruh krisis finansial global atas tingkat kredit macet yang disalurkan kedua jenis perbankan. Pengujian menunjukkan krisis keuangan global yang terjadi tahun lalu tidak berpengaruh terhadap tingkat NPF bank syariah. Hal ini semakin memperkuat bukti bahwa bank syariah merupakan model perbankan yang tahan atas guncangan krisis. Hasil ini juga menunjukkan kualitas penyaluran dan monitoring kredit yang dilakukan bank syariah menjadi model bagi bank umum untuk mengurangi kredit macet, terutama pola pembiayaan yang dilakukan dengan akad syar'I, tidak sekedar menarik biaya (interest) atas pinjaman namun turut serta melakukan profit and loss sharing. Kondisi sebaliknya terjadi di perbankan konvensional yang riskan terhadap krisis.

Perbankan konvensional terlihat cukup terpengaruh oleh krisis keuangan global (variabel dummy signifikan) sehingga riskan pula mengalami kesulitan likuiditas. Pemerintah bersama BI membuat langkah-langkah untuk menyelamatkan beberapa bank konvensional dari potensi kebangkrutan. Bukan sekedar kerugian pada level institusi semata yang dihadapi tetapi lebih karena sistem perbankan konvensional saat ini saling terhubung (dependency) sehingga apabila terjadi kebangkrutan pada satu bank dapat berakibat sistemik berupa terseretnya bank-bank lain untuk kolaps. Bank Century dapat menjadi contohnya. Tingkat pendapatan juga cukup berpengaruh (sig 5\%) pada tingkat kredit bermasalah bank konvensional. Tetapi pengaruhnya justru positif, artinya semakin besar pendapatan masyarakat tingkat kredit bermasalah bukannya turun tetapi ikut naik. Padahal seharusnya bila pendapatan masyarakat naik maka tingkat kredit bermasalah menjadi berkurang. Inilah missing link yang menjadi pertanyaan besar saat ini. Lalu apa penyebab kondisi tersebut? Penjelasan paling rasional dalam hal ini adalah adanya faktor lain penyebab utama kredit bermasalah di bank konvensional. Salah satunya bank dan tingkat inflasi.

Hasil uji VAR sebelumnya juga menunjukkan bahwa hubungan NPL dan LDR justru bernilai negatif. Jika bank mengeluarkan kredit lebih banyak maka tingkat kredit bermasalah akan turun. Jika alasan kredit macet lebih disebabkan oleh faktor teknis, besarnya alokasi pinjaman harusnya akan menambah jumlah kredit bermasalah. Artinya faktor penyebab kredit bermasalah di bank konvensional tidak semata aspek teknis tetapi variabel yang lebih kompleks melibatkan keperilakuan dan aspek makro yaitu inflasi, suku bunga, dan sebagainya. Hal ini berarti bahwa posisi bank konvensional lebih rapuh terhadap guncangan krisis dibanding bank syariah yang tahan dan mandiri.

Beberapa temuan di atas juga dapat digunakan sebagai jawaban atas hasil 
Ihda A Faiz: Ketahanan Kredit Perbankan Syariah...

penelitian Choong dan Liu ${ }^{33}$ yang menunjukkan bukti empiris bahwa sistem perbankan syariah dengan sampel Malaysia tidak jauh beda dengan sistem perbankan konvensional. Hal ini ditunjukkan dengan adanya keterkaitan (kausalitas) antara deposito perbankan Islam dan konvensional. Perbankan Islam tidak sepenuhnya menerapkan sistem bagi hasil (profit and loss sharing/PLS) yang bebas bunga (intereet free) karena ternyata deposito Islam dipengaruhi kuat oleh tingkat suku bunga deposito bank konvensional. Dua kemungkinan penyebabnya yaitu konsep pendanaan PLS dihadapkan pada problem agency theory atau bisa jadi pola pengelolaan dana syariah masih disandarkan pada praktek berbasis bunga (interest based). Kondisi tersebut bisa saja terjadi bila dalam perkembangannya Malaysia lebih bersifat liberal dalam mengeluarkan fatwaizin produk perbankan syariah untuk menggenjot pertumbuhan.

Jika tidak ditangani oleh dewan pengawas syariah yang kapabel (faqih) dan kurangnya kontrol kehati-hatian (prudential monitoring) atas perbankan syariah dikhawatirkan akan terjadi moral hazard dalam pengelolaan dana nasabah di lapangan. Berbeda dengan kondisi Indonesia yang ulamanya dikenal cukup rigid (ketat) dalam mengeluarkan fatwa kehalalan produk perbankan syariah, praktik perbankan syariah justru berjalan lebih aman, murni dan sustainable. Itulah mengapa perkembangan bank syariah di Indonesia dinilai cukup lambat dibanding Malaysia. Berbagai jenis dan model krisis keuangan pun tidak akan menjangkiti perekonomian yang dibangun berdasarkan ketentuan Islam. Dari sisi makroekonomi temuan Ascarya ${ }^{34}$ menunjukkan kecilnya porsi model perekonomian Islam dalam penciptaan krisis keuangan global tahun lalu. Dari sisi mikrronya, hasil penelitian ini memperkuat karakter ketahanan model bisnis Islam dan watak kemandirian yang diciptakannya dibanding sistem saat ini.

\section{KESIMPULAN}

Penelitian ini semakin memperkuat hasil dari beberapa penelitian sebelumnya yang menggambarkan stabilitas perbankan syariah serta keunggulan sistem kerja dan produk yang ditawarkan dibanding perbankan konvensional. Faktor yang berpengaruh negatif dan signifikan terhadap NPF bank syariah adalah besarnya jumlah pembiayaan dan tingkat PDB. Sedangkan nilai tukar berpengaruh negatif namun tidak cukup signifikan. Sedangkan indikator makroekonomi lainnya (inflasi, SBI, SWBI) tidak berpengaruh terhadap NPF bank syariah. Di sisi lain tingkat NPL bank konvensional sangat tergantung pada tingkat inflasi yang terjadi (positif) dan besarnya LDR (negatif). Hal ini juga menunjukkan ketergantungan bank konvensional pada bunga dan sektor keuangan. Hubungan NPL danLDR yang negatif menunjukkan tidak berfungsinyaaspek intermediary bank konvensional terhadap dunia usaha sehingga memperparah decoupling sektor riil dan moneter. Temuan lain menunjukkan bahwa besarnya NPL bank konvensional terpengaruh krisis keuangan global yang terjadi tahun lalu sedangkan di bank syariah cenderung resisten.

${ }^{33}$ Beng Soon Choong dan Ming-Hua Liu (2008), "Islamic..., ibid.

${ }^{34}$ Ascarya (2009), ibid. 
Ihda A Faiz: Ketahanan Kredit Perbankan Syariah...

\section{DAFTAR PUSTAKA}

Anto, MB Hendrie dan Setyowati, Desti (2008), "The Indicatioan of Moral Hazard in Islamic Financing: A ComparativeStudy Between Islamic Bank and Conventional Bank in Indonesia 2003:1 - 2007:9”, Paper Symposium “On Implementation of Islamic to Positive Economics in the Worldas Anlternative of Conventional Economic System: Toward development in the new Era of The Holistic Economics". Universitas Airlangga Surabaya 1-3 Agustus 2008.

Ascarya (2009), "Pelajaran yang dapat dipetik dari Krisis Berulang: Perpektif Ekonomi Islam”, Buletin EkonomiMoneter dan Perbankan, Volume 12 Nomor 1Juli2009, pp. 33-82.

Audretsch, David B dan Thurik, Roy, (2000), "Capitalism and Democracy in the 21 1 " Century: From the Managed to the Entrepreneurial Economy”, Journal of Evolutionary Economics, 10, pp. 17-34.

Boumediene, Aniss dan Caby, Jerome (2010), “The Stablity of Islamic Banks During Subprime Crisis. Available", dikutip dari http://ssrn.com/abstract =1524775, diakses 11 Agustus 2010.

Choong, Beng Soon dan Liu, Ming-Hua (2008), "Islamic Banking: Interest-Free or Interest-Based?" dikutip dari http://ssrn.com/abstract $=868567$, diakses $1 \mathrm{Juni}$ 2010.

Christmas, Eduardus (2009), "Entrepreneurship Capital dan Pertumbuban Manufaktur Regional Studi Empiris Provinsi Jawa Timur Tahun 2000-2005”, Skripsi FE UI. Tidak dipublikasikan.

Èihák, Martin dan Hesse, Heiko (2008), "Islamic Bank and Financial Stability: An Empirical Analysis”, IMF Working Paper No. WP/06/08.

Lu, Shandre Ding dan Hu, Qing (2001), The Link Between Behaviour And Non Performing Loan In China. Internet

Enders, Walter (2004), Applied Econometric Time Series. New York: John Wiley and Sons, Inc.

Faiz, Ihda A. (2010), “Analisis Stabilitas Perbankan Syariah di Indonesia dan Faktor Yang Mempengarubinya”, Jurnal Ekonomidan Bisnis Islam (Ekbisi), Forthcoming.

Godlewski, Christophe J. (2004), "Excess Credit Risk and Bank's Default Risk An Application of Default Prediction's Modelsto Banksfrom Emerging Market Economics”, Financial Economics and Financial Econometrics. Germany

Gujarati, Damodar N. (2003), Basic Econometrics, Fourth Edition-International Edition, Singapura: McGraw Hill.

Hadi, Yonathan S. (2003), “Analisis Vector Auto Regression(VAR)Terhadap Korelasi Antara Pendapatan Nasional dan Investasi Pemerintah Indonesia, 1983/1984-1999/ 2000", Jurnal Keuangan dan Moneter, Volume 6 Nomor 2. 
Ihda A Faiz: Ketahanan Kredit Perbankan Syariah...

Haniffa, Roszaini dan Hudaib, Mohammad (2007), "Exploring the Ethical Identity of Islamic Banks via Communication in Annual Reports", Journal of BusinessEthics, 76, pp. 97-116.

Honohan, JF dan C., James (1997), “Banking System Failures In Developing And Transition Countries: Diagnosis And Predictions”, BIS Working Paper 39.

Kittikulsingh, Suthep (1999), "Non Performing Loans(NPLs): The Borrower's Viewepoint”, TDRI Quarterly Review, Vol 14 No. 4 December 1999.

Office of the Comptroller of the Currency (1988), "Bank Failure an Evaluation of the Factors Contributing to the Failure of National Banks", dikutip dari www.occ.gov/static/publications/bankfailure.pdf diakses 1Juni 2010.

Prima, Rizal Adi (2004), "Disparitas Efek Regional dan Faktor Penentu Transmisi Kebijakan Moneter Daerab: Kasus Sumatra-Jawa”, Skripsi Fakultas Ekonomi Universitas Indonesia. Tidak dipublikasikan.

Rahmawulan, Yunis (2008), "Perbandingan Faktor Penyebab Timbulnya NPL dan NPF pada perbankan Konvensional dan Syariab di Indonesia”, Tesis Program Kajian Timur Tengah dan Islam Universitas Indonesia. Tidak dipublikasikan.

Sims, C. A. (1980), "Macroeconomics and Reality”, Econometrica, Vol.48, 1980, pp. 1-48.

Wu, Chang dan Selvili. 2003. Banking System, Real Estate Markets and Non Performing Loans. International Real Estate Review. Vol 6 No 1, pp. 43-62. 
Ihda A Faiz: Ketahanan Kredit Perbankan Syariah...

\section{LAMPIRAN}

Tabel 1

Uji Stasioneritas data

\begin{tabular}{|l|l|l|l|l|l|}
\hline Variabel & PP Test & $1 \%$ & $5 \%$ & $10 \%$ & Tingkat Stasioner \\
\hline NPL & -3.897334 & -3.6959 & -2.9750 & -2.6265 & $1^{\text {st }}$ diff \\
\hline NPF & -3.107722 & -3.6852 & -2.9705 & -2.6242 & Level \\
\hline SBI & -3.242105 & -3.6959 & -2.9750 & -2.6265 & $1^{\text {st }}$ diff \\
\hline SWBI & -3.248141 & -3.6852 & -2.9705 & -2.6242 & Level taraf 5\% \\
\hline LOAN & -9.324843 & -3.6852 & -2.9705 & -2.6242 & Level \\
\hline FIN & -3.265747 & -3.6852 & -2.9705 & -2.6242 & Level taraf 5\% \\
\hline LDR & -11.70993 & -3.6852 & -2.9705 & -2.6242 & $1^{\text {st }}$ diff \\
\hline FDR & 3.185055 & -3.6852 & -2.9705 & -2.6242 & Level \\
\hline GDP & -5.267110 & -3.6852 & -2.9705 & -2.6242 & Level \\
\hline INF & -4.910236 & -3.6959 & -2.9750 & -2.6265 & $1^{\text {st }}$ diiff \\
\hline EXR & -4.749061 & -3.6852 & -2.9705 & -2.6242 & Level \\
\hline
\end{tabular}

Penentuan order lag model perbankan syariah

Tabel 2

VAR Lag Order Selection Criteria Sharia Banking

\begin{tabular}{ccccccc}
\hline \hline Lag & LogL & LR & FPE & AIC & SC & HQ \\
\hline \hline 0 & 202.4373 & NA* & $1.50 \mathrm{E}-12$ & -15.87498 & $-15.67996^{*}$ & -15.82089 \\
1 & 216.0395 & 21.76352 & $1.86 \mathrm{E}-12$ & -15.68316 & -14.70806 & -15.41271 \\
2 & 233.7540 & 22.67457 & $1.81 \mathrm{E}-12$ & -15.82032 & -14.06514 & -15.33351 \\
3 & 247.7506 & 13.43679 & $2.92 \mathrm{E}-12$ & -15.66005 & -13.12479 & -14.95688 \\
4 & 283.1185 & 22.63542 & $1.30 \mathrm{E}-12^{*}$ & $-17.20948^{*}$ & -13.89414 & $-16.28994^{*}$ \\
\hline \hline
\end{tabular}

* indicates lag order selected by the criterion

Penentuan order lag model perbankan konvensional

Tabel 3

VAR Lag Order Selection Criteria Conventional Banking

\begin{tabular}{ccccccc}
\hline \hline Lag & LogL & LR & FPE & AIC & SC & HQ \\
\hline \hline 0 & 222.3576 & NA & $3.05 \mathrm{E}-13$ & -17.46861 & -17.27359 & -17.41452 \\
1 & 264.3006 & 67.10880 & $3.91 \mathrm{E}-14$ & -19.54405 & $-18.56895^{*}$ & -19.27360 \\
2 & 279.6832 & 19.68964 & $4.60 \mathrm{E}-14$ & -19.49465 & -17.73947 & -19.00784 \\
3 & 311.5598 & $30.60161^{*}$ & $1.77 \mathrm{E}-14$ & -20.76479 & -18.22953 & -20.06161 \\
4 & 337.1322 & 16.36632 & $1.73 \mathrm{E}-14^{*}$ & $-21.53058^{*}$ & -18.21523 & $-20.61104^{*}$ \\
\hline \hline
\end{tabular}

* indicates lag order selected by the criterion

Tabel 4 Var Stability Condition Check Lag 1 Perbankan Syariah

Roots of Characteristic Polynomial Sharia Banking

\begin{tabular}{cc}
\hline \hline Root & Modulus \\
\hline \hline 0.659459 & 0.659459 \\
0.204376 & 0.204376 \\
-0.058923 & 0.058923 \\
0.041813 & 0.041813 \\
\hline \hline
\end{tabular}


Ihda A Faiz: Ketahanan Kredit Perbankan Syariah...

Roots of Characteristic Polynomial Conventional Banking

\begin{tabular}{ll}
\hline \hline Root & Modulus \\
\hline \hline 0.959639 & 0.959639 \\
$0.624888-0.049125 \mathrm{i}$ & 0.626816 \\
$0.624888+0.049125 \mathrm{i}$ & 0.626816 \\
0.052381 & 0.052381 \\
\hline \hline
\end{tabular}

Unrestricted Cointegration Rank Test

\begin{tabular}{ccccc}
\hline \hline $\begin{array}{c}\text { Hypothesized } \\
\text { No. of CE }(\mathrm{s})\end{array}$ & Eigenvalue & $\begin{array}{c}\text { Trace } \\
\text { Statistic }\end{array}$ & $\begin{array}{c}\text { 5 Percent } \\
\text { Critical Value }\end{array}$ & $\begin{array}{c}\text { 1 Percent } \\
\text { Critical Value }\end{array}$ \\
\hline \hline None ** & 0.552649 & 60.84931 & 47.21 & 54.46 \\
At most 1 $^{* *}$ & 0.469143 & 38.32579 & 29.68 & 35.65 \\
At most 2 $^{* *}$ & 0.429182 & 20.59443 & 15.41 & 20.04 \\
At most 3 $^{*}$ & 0.160402 & 4.895282 & 3.76 & 6.65 \\
\hline \hline
\end{tabular}

Unrestricted Cointegration Rank Test

\begin{tabular}{ccccc}
\hline \hline $\begin{array}{c}\text { Hypothesized } \\
\text { No. of CE(s) }\end{array}$ & Eigenvalue & $\begin{array}{c}\text { Trace } \\
\text { Statistic }\end{array}$ & $\begin{array}{c}5 \text { Percent } \\
\text { Critical Value }\end{array}$ & $\begin{array}{c}\text { 1 Percent } \\
\text { Critical Value }\end{array}$ \\
\hline \hline None & 0.466728 & 39.32222 & 47.21 & 54.46 \\
At most 1 & 0.347774 & 22.34669 & 29.68 & 35.65 \\
At most 2 & 0.295663 & 10.80785 & 15.41 & 20.04 \\
At most 3 & 0.048573 & 1.344389 & 3.76 & 6.65 \\
\hline \hline
\end{tabular}

$*(* *)$ denotes rejection of the hypothesis at the $5 \%(1 \%)$ level

Trace test indicates no cointegration at both $5 \%$ and $1 \%$ levels

Dependent Variable: NPF

\begin{tabular}{crrrr}
\hline \hline Variable & Coefficient & Std. Error & t-Statistic & Prob. \\
\hline \hline C & 0.041621 & 0.004974 & 8.367582 & 0.0000 \\
DUM & -0.000164 & 0.004852 & -0.033852 & 0.9733 \\
FIN & -0.069444 & 0.029934 & -2.319899 & 0.0292 \\
GDP & 0.147860 & 0.064702 & 2.285255 & 0.0314 \\
EXR & -0.037973 & 0.034200 & -1.110321 & 0.2779 \\
R-squared & 0.390619 & & & \\
Prob(F-statistic) & 0.014914 & & & \\
\hline \hline
\end{tabular}


Ihda A Faiz: Ketahanan Kredit Perbankan Syariah...

Dependent Variable: NPL

\begin{tabular}{crrrr}
\hline \hline Variable & Coefficient & Std. Error & t-Statistic & Prob. \\
\hline \hline C & 0.077135 & 0.018292 & 4.216871 & 0.0003 \\
DUM & -0.018484 & 0.006230 & -2.967110 & 0.0067 \\
INF & 0.129620 & 0.103490 & 1.252490 & 0.2225 \\
LDR & -0.063805 & 0.021382 & -2.984084 & 0.0064 \\
SBI & 0.223421 & 0.191261 & 1.168147 & 0.2542 \\
R-squared & 0.739154 & & & \\
Prob(F-statistic) & 0.000001 & & & \\
\hline \hline
\end{tabular}

Response to Cholesky One S.D. Innovations

Response of NPF to FIN

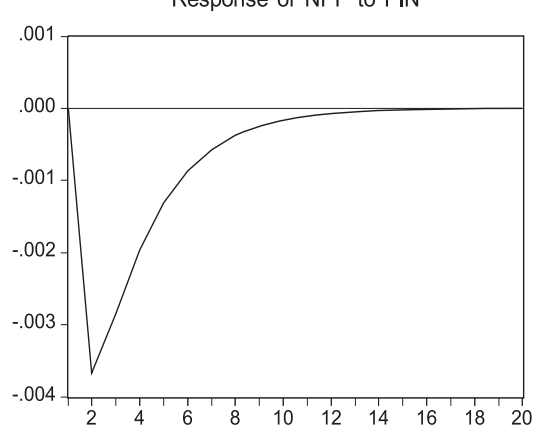

Response of NPF to GDP
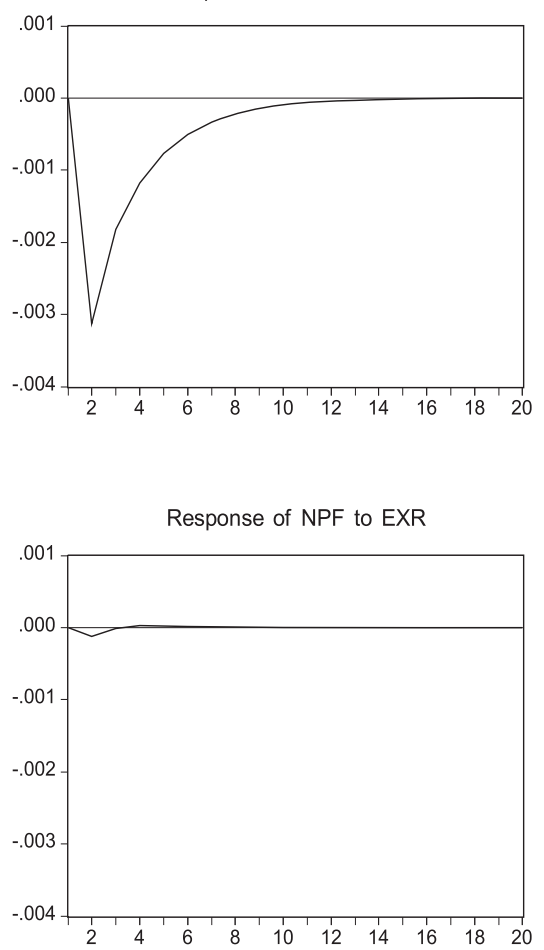

Response to Cholesky One S.D. Innovations

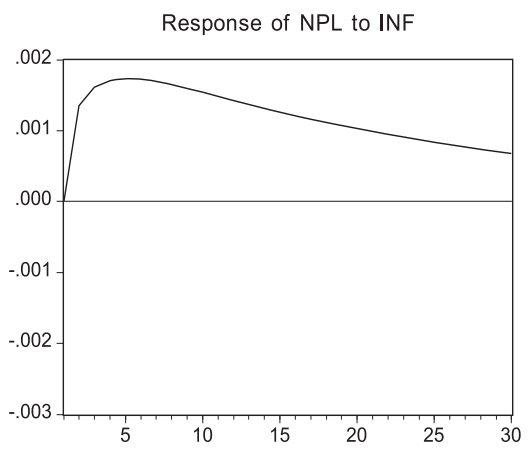

Response of NPL to LDR

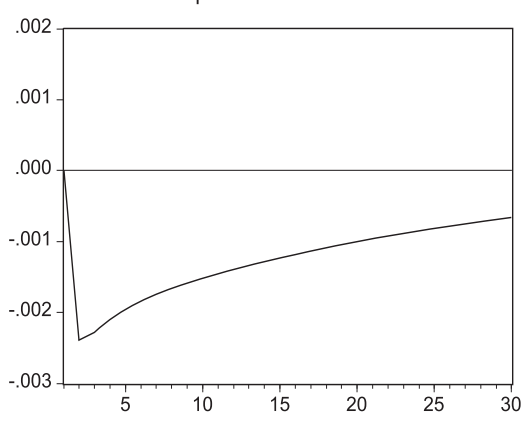

Response of NPL to SBI

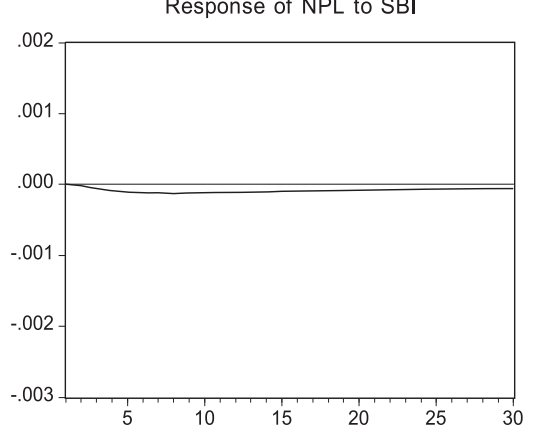

